\title{
Molecular phylogenetic analysis of a scale insect (Drosicha mangiferae; Hemiptera: Monophlebidae) infesting mango orchards in Pakistan
}

\author{
Muhammad ASHFAQ ${ }^{1}$, Jehan ARA ${ }^{1}$, Ali Raza NOOR ${ }^{1}$, Paul D.N. HEBERT ${ }^{2}$ and Shahid MANSOOR ${ }^{1}$ \\ ${ }^{1}$ National Institute for Biotechnology and Genetic Engineering (NIBGE), Jhang Road, 38000 Faisalabad, Pakistan; \\ e-mails: muhammadashfaq@hotmail.com; ashfaqm@nibge.org \\ ${ }^{2}$ Biodiversity Institute of Ontario, University of Guelph, Canada; e-mail: phebert@uoguelph.ca
}

Key words. Hemiptera, Monophlebidae, mango mealybug, Drosicha mangiferae, rDNA, COI, ITS1

\begin{abstract}
Mango orchards in Pakistan are attacked by the scale insect, Drosicha mangiferae (Hemiptera: Monophlebidae), commonly called the "mango mealybug". This insect is univoltine, active from December through May and targets multiple host plants. We used DNA nucleotide sequences to characterize and determine the phylogenetic status of D. mangiferae. Mango mealybugs were collected from several tree species from different localities and patterns of phylogenetic and genetic diversity were examined at both nuclear (18S, ITS1) and mitochondrial (COI) genes. Phylogenetic analysis confirms that the mango mealybug belongs to the family Monophlebidae. Minor genetic differences in both the ITS1 and the COI barcode region were noted among D. mangiferae collected from different geographic localities. These genetic differences revealed the existence of two genotypes of D. mangiferae that are region specific but not host-specific.
\end{abstract}

\section{INTRODUCTION}

Mango orchards in Pakistan are attacked by an insect belonging to the superfamily Coccoidea (Ben-Dov et al., 2006) called the "mango mealybug" which results in heavy fruit losses every year. Gravid females of this univoltine insect leave the trees in May-June, laying their eggs in the soil near the tree trunks and in December-January newly hatched nymphs crawl up the trees to feed. Nymphs and adults damage plants by sucking sap from inflorescences, shoots and fruit peduncles. This results in shriveled twigs and leaves and heavy fruit drop. The major target of mango mealybug is mango trees, but it has also become a pest on citrus and several other tree species.

Four coccid species have been reported as pests on mango trees including Drosicha mangiferae, $D$. stebbingi, R. iceryoides, and Rastrococcus invadens (Latif, 1961; Tandon \& Lal, 1978; Williams, 1986; Willink \& Moore, 1988). R. invadens is a serious pest of mango and other fruit trees in Africa (Agounké et al., 1988; Moore, 2004), whereas $R$. iceryoides has been reported on ornamental and forest trees as well (Sundararaj \& Devaraj, 2010). D. mangiferae and D. stebbingi have been reported as mango pests in Pakistan (Latif, 1949, 1961). Due to their morphological similarity, D. mangiferae and D. stebbingi have often been treated as synonyms. Beeson (1941) stated that D. stebbingi is largely a pest of forest trees while $D$. mangiferae is a pest of fruit trees, but other authors have concluded that fruit trees are common hosts for both $D$. mangiferae and $D$. stebbingi. This confusion provoked re-examination of the mango mealybug status. Latif (1961) concluded that $D$. mangiferae and D. stebbingi not only share food plants, but that it was highly probable that $D$. mangiferae was synonymous with D. stebbingi. However, confusion still prevails as some authors continue to report mealybugs from forest trees as D. stebbingi (Gul et al., 1997).

The identification of scale insects to a species level is often challenging due to their reduced morphology, and the high similarity of their immature stages (Miller, 2002; Watson \& Kubiriba, 2005). Because the use of standard taxonomic characters for identification has proven difficult (Danzing, 1997; Gullan \& Cook, 2007), various molecular markers have been used to differentiate species and to ascertain evolutionary relationships (Beuning et al., 1999; Mowry \& Barbour, 2004; Gadagkar et al., 2005; Gariepy et al., 2007). In some cases, molecular phylogenetic analyses have been combined with morphological characters to assess taxonomic relationships (Hardy et al., 2008). The most commonly used genes for the differentiation of insect species have been ribosomal RNA (18S, 28S, internal transcribed spacers) and mitochondrial cytochrome $c$ oxidase I (COI) (Simon et al., 1994; Li et al., 2005). In fact, sequence diversity in the $5^{\prime}$ region of the COI gene has been established as the standard for species identification across the animal kingdom (Hebert et al., 2003; Miller, 2007; Linares et al., 2009). Several prior studies (Hardy et al., 2008; Rung et al., 2008; Ashfaq et al., 2010) have examined mealybug classification based on sequence variation in ribosomal and mitochondrial DNA. Similarly, sequence data of nuclear, mitochondrial and endosymbiotic genes have been used to estimate the phylogenies of scale insects (Cook et al., 2002; Morse \& Normark, 2006; Gullan \& Cook, 2007). These studies have established the value of molecular techniques in both species identification and in assessing phylogenetic relationships. 
There is little information on the molecular identification, genetic relationships and species composition in mango mealybugs from different geographical areas or on various host plants in Pakistan. In fact, as already noted, confusion prevails about the species of mealybug attacking mango and other fruit and forest trees. The present study seeks to genetically characterize the mango mealybug to investigate the species composition by examining genotypic variation amongst its populations. The resultant information may aid pest management programs by allowing the implementation of a speciesspecific biological control strategy on mango mealybug.

\section{MATERIAL AND METHODS}

Both adult females and nymphs of the mango mealybug were collected during April-May 2008/2009 from fruit and forest trees. DNA was either extracted immediately or specimens were preserved in $95 \%$ ethanol and held at $-20^{\circ} \mathrm{C}$ until use. DNA was extracted from the heads of the fresh/preserved specimens as described earlier (Erlandson et al., 2003). Briefly, insects were homogenized individually in Lifton buffer (100 mM Tris-HCl, $\mathrm{pH} 7.5,50 \mathrm{mM}$ EDTA, 0.5\% SDS, and $0.2 \mathrm{M}$ sucrose), proteins were precipitated by $8 \mathrm{M}$ potassium acetate, and finally DNA was purified by repeated phenol-chloroform extractions. Precipitated DNA pellets were re-suspended in $50 \mu \mathrm{l}$ of distilled water with $0.5 \mu \mathrm{l}$ of $10 \mathrm{mg} / \mathrm{ml}$ of RNase A.

\section{PCR, cloning and sequencing}

Partial fragments of $18 \mathrm{~S}$ rRNA and internal transcribed spacer (ITS1), and the 3' end of mitochondrial COI were amplified using primers and PCR conditions as described earlier (Ashfaq et al., 2010). PCR products were visualized under UV light on $1.2 \%$ agarose gels and excised and purified using a QIAquick gel extraction kit (Qiagen Inc. USA) following the manufacturer's protocols, and subsequently cloned into the pTZ57R/T vector (InsTAclone PCR Cloning Kit, Fermentas, Inc. USA). Recombinant colonies were inoculated into $4 \mathrm{ml}$ of LB/ampicillin cultures and plasmid DNA was extracted using GeneJET Plasmid Miniprep Kit (Fermentas, Inc. USA). At least two cloned PCR product plasmids from the DNA of individual insects from various localities were sequenced commercially (Macrogen, Inc. South Korea). Amplification and sequencing of the COI barcode region were performed at the Canadian Centre for DNA Barcoding (CCDB) at the Biodiversity Institute of Ontario following standard protocols (Hebert et al., 2003).

\section{Nucleotide sequence alignments and phylogenetic analysis}

PCR amplicons were bidirectionally sequenced and contigs were assembled and edited using EditSeq (DNAStar, Madison, WI). Nucleotide sequences of $18 \mathrm{~S}$ rRNA and COI of additional mealybug and scale species obtained from GenBank (NCBI) were aligned to determine evolutionary relationships of $D$. mangiferae. Multiple alignments were carried out under the profile alignment option with ClustalW using the default parameters. Phylogenetic and molecular evolutionary analyses were conducted and dendrograms constructed using MEGA version 4 (Tamura et al., 2007). Patterns of sequence divergence among taxa were visualized using the neighbor-joining method. Evolutionary distances were computed using the Maximum Composite Likelihood method based upon the number of base substitutions per site after all positions containing gaps and missing data were eliminated from the dataset (Complete Deletion model).

TABLE 1. Nucleotide variation in the barcode region of COI among specimens of Drosicha mangiferae collected from different host-plants in three regions of Pakistan.

\begin{tabular}{|c|c|c|c|c|c|c|c|}
\hline \multirow{4}{*}{ Region } & \multirow{4}{*}{ Specimen ID / Accession No. (GPS Coordinates) / Host } & \multicolumn{6}{|c|}{ Nucleotide position $^{a}$} \\
\hline & & 36 & 110 & 186 & 258 & 417 & 463 \\
\hline & & \multicolumn{6}{|c|}{ Consensus sequence } \\
\hline & & $\mathrm{T}$ & $\mathrm{T}$ & $\mathrm{C}$ & $\mathrm{C}$ & $\mathrm{G}$ & $\mathrm{T}$ \\
\hline \multirow{5}{*}{ Southern } & IMB452 / JF792876 (30¹6N, 71 $\left.{ }^{\circ} 45 \mathrm{E}\right) /$ Mangifera indica & . & $\mathrm{C}$ & . & . & . & . \\
\hline & IMB453 / JF792875 (30¹6N, 7145E) / Ziziphus jujuba & . & $\mathrm{C}$ & . & . & . & . \\
\hline & IMB454 / JF792874 (30¹6N, 7145E)/ Mangifera indica & . & $\mathrm{C}$ & . & . & . & . \\
\hline & IMB2 14 / HM891565 (2545N, 68²71E) / Mangifera indica & . & $\mathrm{C}$ & . & . & . & . \\
\hline & IMB455 / JF792873 (2541N, 6853E) / Citrus sp. & . & $\mathrm{C}$ & . & . & . & . \\
\hline \multirow{10}{*}{ Central } & IMB210 / HM388808 $\left(31^{\circ} 34 \mathrm{~N}, 73^{\circ} 29 \mathrm{E}\right) /$ Mangifera indica & $\mathrm{C}$ & . & . & . & . & . \\
\hline & 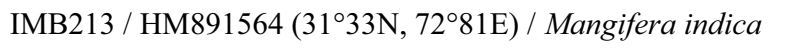 & . & . & . & . & . & . \\
\hline & IMB211 / HM891563 (3130N, 7321E) / Alstonia sp. & $\mathrm{C}$ & . & . & . & . & . \\
\hline & IMB448 / JF792879 $\left(31^{\circ} 50 \mathrm{~N}, 73^{\circ} 35 \mathrm{E}\right) /$ Eugenia jambolana & . & $\mathrm{C}$ & . & . & . & . \\
\hline & IMB447 / JF792880 (31ํ33N, 7281E) / Citrus sp. & . & . & . & . & . & . \\
\hline & IMB446 / JF792881 (3156 N, 7348E) / Melia azedarach & $\mathrm{C}$ & . & . & . & . & . \\
\hline & IMB449 / JF792878 (31ํ53N, 74³1E) / Mangifera indica & . & . & . & . & . & . \\
\hline & IMB450 / JF792877 (31535N, 74³1E) / Alstonia sp. & . & . & . & . & . & . \\
\hline & IMB215 / HM388809 $\left(31^{\circ} 51 \mathrm{~N}, 74^{\circ} 33 \mathrm{E}\right) /$ Eugenia jambolana & . & . & . & . & . & . \\
\hline & IMB445 / JF792882 (31ํ6N, 74²1E) / Citrus sp. & . & . & $\mathrm{T}$ & $\mathrm{T}$ & A & $\mathrm{C}$ \\
\hline \multirow{5}{*}{ Northern } & IMB209 / HM388807 (3553N, 7245E) / Ziziphus jujuba & . & . & $\mathrm{T}$ & $\mathrm{T}$ & A & $\mathrm{C}$ \\
\hline & IMB456 / JF792872 (3553N, 7245E) / Ziziphus jujuba & . & . & $\mathrm{T}$ & $\mathrm{T}$ & A & $\mathrm{C}$ \\
\hline & IMB457 / JF792871 (3553N, 7245E) / Acacia indica & . & . & $\mathrm{T}$ & $\mathrm{T}$ & A & $\mathrm{C}$ \\
\hline & IMB458 / JF792870 $\left(34^{\circ} 32 \mathrm{~N}, 71^{\circ} 32 \mathrm{E}\right) /$ Ziziphus jujuba & . & . & $\mathrm{T}$ & $\mathrm{T}$ & A & $\mathrm{C}$ \\
\hline & IMB459 / JF792869 $\left(34^{\circ} 32 \mathrm{~N}, 71^{\circ} 32 \mathrm{E}\right) /$ Acacia indica & . & . & $\mathrm{T}$ & $\mathrm{T}$ & A & $\mathrm{C}$ \\
\hline
\end{tabular}

${ }^{a}$ Position in a $531 \mathrm{bp} 5$ '-end barcode fragment of COI. Dots indicate the consensus nucleotides. 


\section{RESULTS}

\section{PCR amplification of the genes}

A 562 bp sequence of $18 \mathrm{~S}$ rRNA was obtained after PCR amplification and cloning. This sequence is available in the DDBJ/EMBL/GenBank databases under accession number AB523733. The blast search (NCBI) revealed the highest nucleotide similarity with Tessarobelus inusitatus and Monophlebulus sp. (96\%) followed by Neohodgsonius sp. (95\%) of the family Monophlebidae.

Amplification of 3 '-end of COI produced a PCR product of $857 \mathrm{bp}$. The sequence was deposited in GenBank under accession number AB523736. The gene was confirmed based on blast search and the nucleotide homologies with COI from other scale insects. Blast search of the COI sequence showed the highest $(88 \%)$ nucleotide identity with that of the giant scale, Drosicha corpulenta.

Sequences for the barcode region of COI were obtained from 20 specimens of mango mealybug collected from various locations and plant hosts in Pakistan. Alignment of a $531 \mathrm{bp}$ fragment showed that all specimens from northern Pakistan showed diagnostic substitutions at four nucleotide positions from specimens collected in the southern and central regions (Table 1). Specimens from different hosts in the same region did not show any consistent sequence differences (Table 1).

A $510 \mathrm{bp}$ fragment was produced using primers targeting ITS1 region that included partial sequences for $18 \mathrm{~S}$ and $5.8 \mathrm{~S}$ rRNA. The consensus ITS1 sequences of specimens collected from southern region (Sin-3) and northern region (Kar-5) were deposited in the DDBJ/ EMBL/GenBank databases under acc. No. AB523735

TABLE 2. Host plants and geographic origin of scale and mealybug species used to determine the phylogenetic relationships of Drosicha mangiferae.

\begin{tabular}{|c|c|c|}
\hline Species name (Accession no.) & Host plant & Geographic origin \\
\hline Erium globosum (AY426020) & Acacia howittii & Australia: Canberra \\
\hline Pseudococcus calceolariae (AY426039) & Citrus sp. & Australia: Canberra \\
\hline Trionymus frontalis (AY426059) & Leymus arenarius & USA: CA, Santa Barbara \\
\hline Planococcus citri (AY426042) & Citrus sinensis & USA: CA, Davis \\
\hline Dysmicoccus ryani (AY426035) & Ornamental juniper & USA: CA, Sacramento \\
\hline Pseudococcus maritimus (AY426043) & Vitis vinifera & USA: WA, Witstrand \\
\hline Dysmicoccus brevipes (AY426046) & under carton with ants & Bolivia: Santa Cruz \\
\hline Paradoxococcus mcdanieli (AY426062) & grass roots & USA: FL, Payne's Prairie \\
\hline Anisococcus adenostomae (AY426070) & Adenostoma fasciculatum & USA: CA, Mix Canyon \\
\hline Anisococcus sp. (AY426017) & Ephredra sp. & USA: UT, Moab \\
\hline Ferrisia malvastra (AY426019) & potato & USA: AZ, Tuczon \\
\hline Ferrisia gilli (AY426067) & Pistacio vera & USA: CA, Tulare \\
\hline Ferrisia virgata (AY426079) & Mangifera indica & Colombia: Cali, Valle \\
\hline Phenacoccus solani (AY426058) & Bidens sp. crown & USA: FL, Vero Beach \\
\hline Phenacoccus madeirensis (AY426025) & Penstemon sp. & USA: CA, Vacaville \\
\hline Phenacoccus solenopsis (AB439210) & Gossypium hirsutum & Pakistan: Faisalabad \\
\hline Heliococcus adenostomae (AY426071) & Adenostoma fasciculatum & USA: CA, Mix Canyon \\
\hline Heliococcus clemente (AY426065) & Gutierrezia sp. & USA: CA, Cuyama Valley \\
\hline Heliococcus bohemicus (HM156737) & Vitis vinifera & Italy: Torino \\
\hline Maconellicoccus australiensis (AY426080) & Acacia dealbata & Australia: Tharwa, ACT \\
\hline Maconellicoccus hirsutus (AY426033) & Hibiscus sp. & Thailand: Chiang Mai \\
\hline Melanococcus albizziae (AF483205) & Acacia spp. & USA \\
\hline Rhizoecus gracilis (AY426074) & Artemisia tridentata & USA: ID, Holbrook Pass \\
\hline Geococcus coffeae (AY426066) & Ptychosperma elegans & USA: CA, Ramona \\
\hline Rhizoecus hibisci (AY426053) & Neodypsis decaryi & USA: Hilo, Hawaii \\
\hline Pulvinaria torreyae (AB439596) & Torreya nucifera & Japan \\
\hline Icerya purchasi (AY426078) & Nandina domestica & USA: CA, Davis \\
\hline Crypticerya townsendi (EU087715) & Gutierrezia sarothrae & USA: UT, Grand Co., BLM \\
\hline Gigantococcus alboluteus (EU087723) & Palm & Ghana: Accra, Hotel Paloma \\
\hline Crypticerya genistae (EU087719) & Legume & USA: FL, Broward Co., Hollywood \\
\hline Icerya aegyptiaca (EU087753) & Macaranga sp. & Thailand: Patong Beach \\
\hline Gueriniella serratulae (EU087754) & Olea sp. & Italy: Imperia \\
\hline Laurencella sp. (EU087759) & Epiphyte mats & Costa Rica: Heredia la virgen \\
\hline Neohodgsonius sp. (EU087758) & Acacia sp. & Belize: Cayo, Chiquibul F.R. \\
\hline Tessarobelus inusitatus (EU087757) & Tristaniopsis callobuxus & New Caledonia: Plaine des Lacs \\
\hline Monophlebus sp. (EU087756) & Allocasuariana distyla & Australia: NSW, Wattamolla \\
\hline Nodulicoccus levis (EU087755) & Eucalyptus pauciflora & Ausstralia: NSW, Carwoola \\
\hline Drosicha corpulenta (AB439510) & Populus alba & Japan \\
\hline Drosicha howardi (AB439511) & Viburnum odoratisimum & Japan \\
\hline Drosicha mangiferae (AB523733) & Mangifera indica & Pakistan: Faisalabad \\
\hline
\end{tabular}


91 CGACGACGCCCCCGTTTAAATTAATACACTATTCGTCTTTTTACGTAGCGGTTCTTGCGGCGTTACGCCTCTGCGTAGAGACGAAAAAAA Kar-5 91 CGACGACGCCCCCGTT--ATTTAATGCACTATTCGTCTTTTTACGAAGCGGTTCTTGCGGCGTTACGCCTCTGCGTAGAGACGAAGAAAA Sin-3

181 AGTATTACAAAATGCGACGCCGCGAAAATATTATAAAAATATTTATTATA------ATATATATTTGAAAAGAAAAA 179 -GTATTACAAAATGCGACGCCGCGAAAATATTATAAAAATATTTATTATATGATGTATATATATTTGAAAAGAAAAA

Fig. 1. Sequence alignment of ITS1 fragments of Drosicha mangiferae from northern (Kar-5) and southern (Sin-3) Pakistan. Nucleotide differences are boxed.

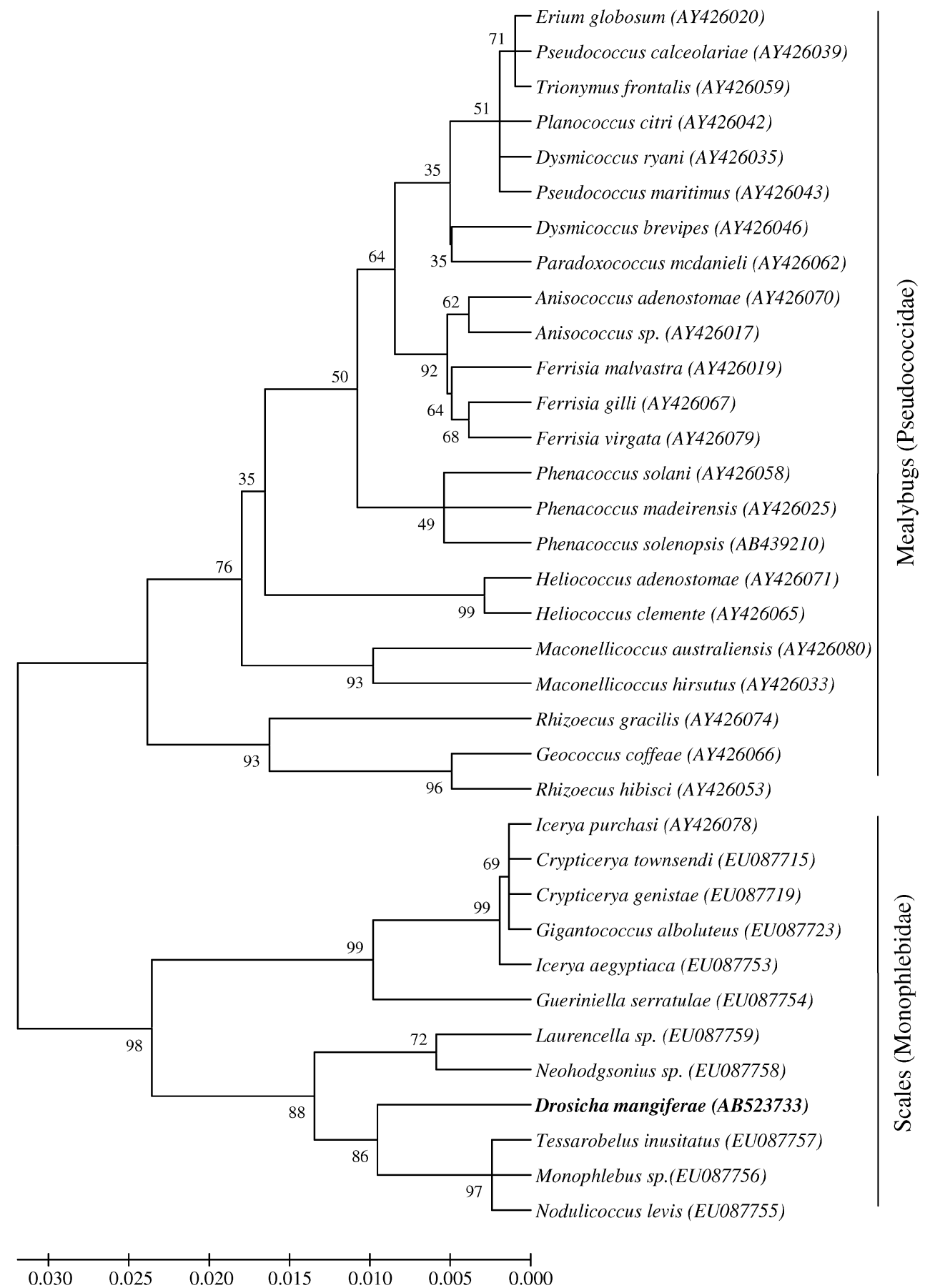

Fig. 2. NJ tree of Drosicha mangiferae with 35 taxa of scale and mealybug species based on 18S rRNA sequences. Bootstrap values ( 500 replicates) for each node are shown next to each branch. All positions containing gaps and missing data were eliminated from the dataset and there were a total of 518 positions in the final dataset. $18 \mathrm{~S}$ rRNA sequences of taxa other than $D$. mangiferae were obtained from GenBank. 


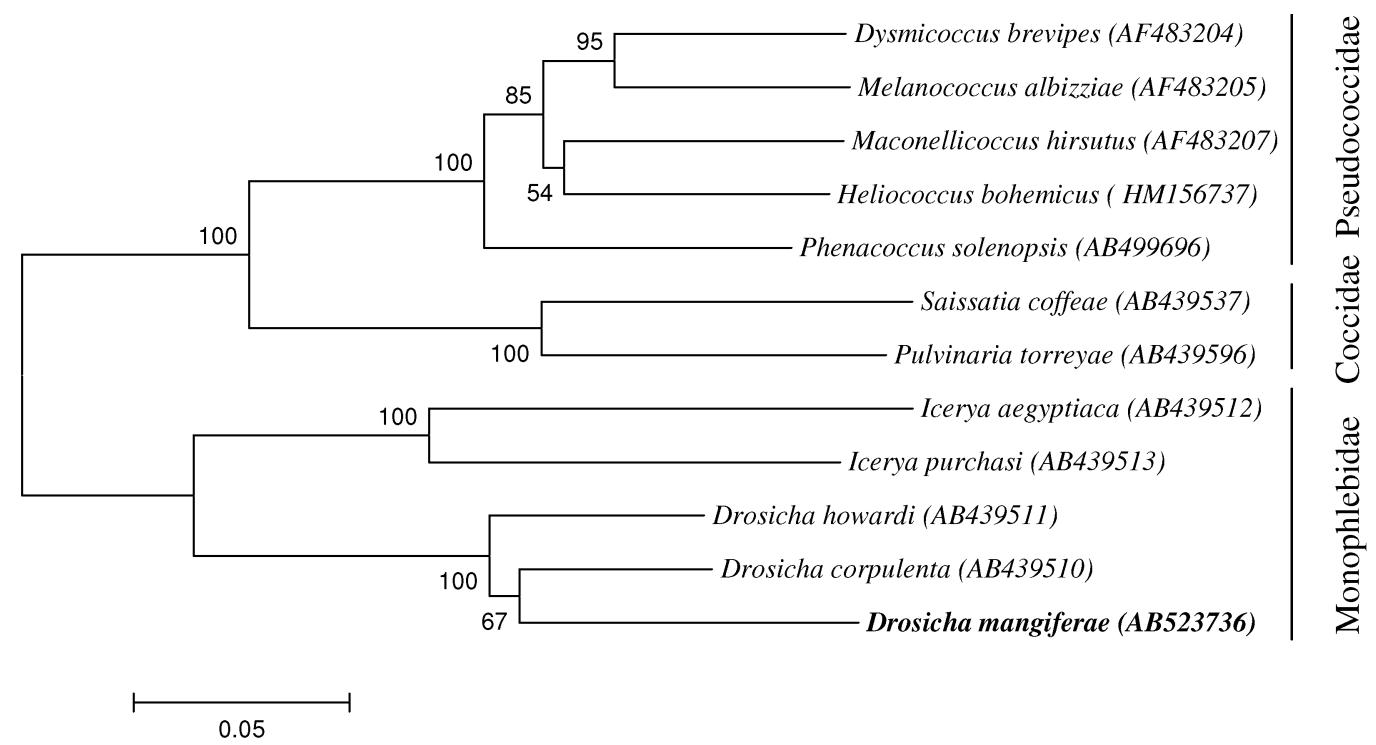

Fig. 3. NJ tree of Drosicha mangiferae with 11 other taxa in the superfamily Coccoidea based on COI sequences. Bootstrap values (500 replicates) for each node are shown next to the branches. The tree is drawn to scale, with branch lengths in the same units as those of the evolutionary distances used to infer the tree. All positions containing gaps or missing data were eliminated from the dataset and there were a total of 808 positions in the final dataset. COI sequences of taxa other than D. mangiferae were obtained from GenBank.

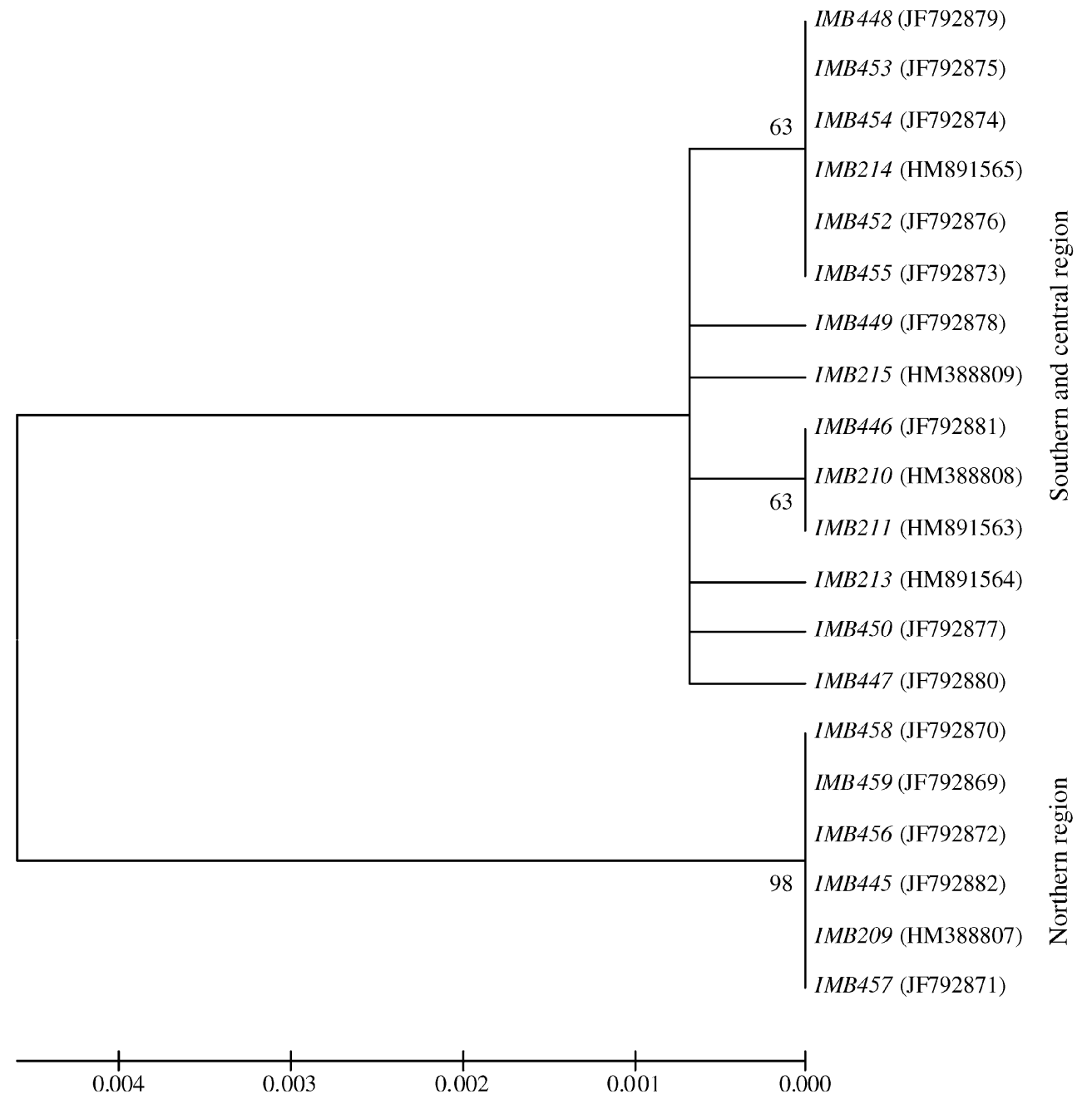

Fig. 4. NJ tree of Drosicha mangiferae specimens collected from different geographical regions of Pakistan. The tree was linearized assuming equal evolutionary rates in all lineages. Bootstrap values (500 replicates) for each node are shown next to the branches. 
and AB623050, respectively. The ITS1 sequence of mango mealybug specimens from northern Pakistan showed several nucleotide substitutions from specimens collected in the central and southern regions. As well, specimens from the northern region (Kar-5) possessed a deletion of six nucleotides (Fig. 1).

\section{Phylogenetic analysis and evolutionary relationships} 18S rDNA

Sequence data for thirty five mealybug and scale insects (superfamily Coccoidea) were aligned to examine their phylogenetic relations. The resultant NeighborJoining tree was well resolved (Fig. 2) with scale and mealybug species forming two distinct clusters in the tree with strong bootstrap support, one of mealybugs (Pseudococcidae) and another of scales (Monophlebidae) (Fig. 2). The scale insects were strongly supported as monophyletic ( $98 \%$ bootstrap support) in this tree, but scales (Monophlebidae) split into two main clusters, one cluster mainly composed of the tribe Iceryini while the other includes species in four tribes (Llaveiini, Monophlebulini, Drosichini and Monophlebini). The tree indicates that $D$. mangiferae is most closely allied to Tessarobelus inusitatus, a member of the tribe Monophlebulini.

\section{COI}

Sequence data for twelve mealybug and scale insects in the superfamily Coccoidea were aligned and phylogenetic relations were determined using Neighbor-Joining analysis. The resultant tree (Fig. 3) is well resolved as the species in each family form a cohesive cluster. The Coccidae show closer affinity to species in the family Pseudococcidae than to members of the family Monophlebidae. Within the family Monophlebidae, Icerya and Drosicha form two clusters each with strong bootstrap support (Fig. 3 ). Sequence data of COI barcode region for twenty $D$. mangiferae specimens collected from different regions and host plants were aligned and phylogenetic relations were determined using neighbor-joining analysis. The resultant tree shows two clusters, one cluster represents the specimens collected from northern region and the second for the specimens from southern and central region (Fig. 4).

\section{DISCUSSION}

We sequenced nuclear and mitochondrial genes from mango mealybug populations, and compared these results with sequence data for other mealybug and scale species to assess phylogenetic relationships. Nucleotide data for all genes sequenced in this study differed from prior entries in GenBank, but the closest matches were to scale species in the family Monophlebidae. Phylogenetic analysis of $18 \mathrm{~S}$ rRNA sequences from 35 mealybug and scale species in the families Pseudococcidae and Monophlebidae revealed that the mango mealybug was closest to $T$. inusitatus, a member of the Monophlebidae. When aligned with COI sequences from other scale and mealybug species, the mango mealybug showed greatest similarity with that of giant scale, $D$. corpulenta. COI-based phylogenetic analysis also placed the mango mealybug in the family Monophlebidae and showed that it is closer to the genus Drosicha than to Icerya.

Previous morphological studies have suggested that the mealybug damaging mango trees in Pakistan is $D$. mangiferae (Latif, 1961), but its close similarity to $D$. stebbingi has left uncertainty (Latif, 1949). Both of these species are endemic to Pakistan and India and have not been reported from any other part of the world. Another serious pest on mango, $R$. invadens, widely distributed in other parts of the world is a true mealybug belonging to the family Pseudococcidae.

Sequence analysis of the COI barcode region and ITS1 of mango mealybugs specimens was performed to study the species composition and to assess the extent of genotypic diversity in mealybug populations. The ITS1 region is highly variable and has previously been used to differentiate insect species (Erlandson et al., 2003; Gariepy et al., 2007) and subspecies (Beuning et al., 1999; Ashfaq et al., 2005). COI is also rapidly evolving and is commonly used to study the species relationships and genetic diversity among populations (Miller, 2007). In our studies we examined specimens of $D$. mangiferae from different geographic locations and from various host plants. Samples collected from northern Pakistan showed several diagnostic substitutions at COI from populations in the southern and central regions. Evidence of similar nucleotide differences were evident in the ITS1, suggesting the existence of two major lineages of mango mealybugs in Pakistan.

Two mealybug species, D. mangiferae and D. stebbingi lack diagnostic morphological differentiation between their nymphal instars (Latif, 1961). Researchers have argued that $D$. mangiferae targets fruit plants while $D$. stebbingi attacks forest trees (Beeson, 1941; Gul et al., 1997). We surveyed mealybugs on both fruit and forest trees at several locations. Sequence analysis of $18 \mathrm{~S}$ rDNA and COI genes did not suggest the presence of two species with differing host plant preferences. COI and ITS1sequences revealed two clusters of genotypes that were region specific but not host-specific. A noticeable difference between northern and southern region of Pakistan is the high altitude and hilly terrain of north versus the lowlands of the south, factors that may have played a role in explaining the regional divergence we detected in D. mangiferae. Other members of the Monophlebidae are typically polyphagous (Unruh \& Gullan, 2008) so the presence of $D$. mangiferae on multiple host plants is not unusual. We conclude that D. mangiferae and D. stebbingi (Latif, 1949) are simply host races of the same species. In conclusion, only one Drosicha species was found attacking both fruit and forest trees in Pakistan. However, the detection of genetic differences among mealybug populations from different regions suggests that mango mealybugs may show variation in important biological attributes across Pakistan.

ACKNOWLEDGEMENTS. We thank staff at the CCDB for help with the DNA barcoding of mealybug specimens. This research was supported by the Higher Education Commission (Pakistan) through a research grant under the "Foreign Faculty 
Hiring Program" to M. Ashfaq. Some sequencing costs were covered by a grant from Genome Canada through the Ontario Genomics Institute to P. Hebert.

\section{REFERENCES}

Agounké D., Agricola U. \& Bokonon-Ganta A. 1988: Rastrococcus invadens Williams (Hemiptera, Pseudococcidae), a serious exotic pest of fruit trees and other plants in West Africa. Bull. Entomol. Res. 78: 695-702.

Ashfaq M., Erlandson M. \& Braun L. 2005: Hyperparasitism by Mesochorus spp. (Hymenoptera: Ichneumonidae) in Peristenus sp. (Hymenoptera: Braconidae) and development of PCR primers for hyperparasitoid detection. Biol. Contr. 32: 371-377.

Ashfaq M., Noor A.R. \& Mansoor S. 2010: DNA-based characterization of an invasive mealybug (Hemiptera: Pseudococcidae) species damaging cotton in Pakistan. Appl. Entomol. Zool. 45: 395-404.

Ben-Dov Y., Miller D.R. \& Gibson G.A.P. 2006: ScaleNet. 21 July 2009. http://www.sel.barc.usda.gov/scalenet/scalenet.htm

BeEson C.F.C. 1941: The Ecology and Control of the Forest Insects of India and the Neighbouring Countries. Vasant Press, Dehra Dun, India, 1007 pp.

Beuning L.L., Murphy P., Wu E., Batchelor T.A. \& Morris B.A.M. 1999: Molecular-based approach to the differentiation of mealybug (Hemiptera: Pseudococcidae) species. J. Econ. Entomol. 92: 463-472.

Cook L.G., Gullan P.J. \& Trueman H.E. 2002: A preliminary phylogeny of the scale insects (Hemiptera: Sternorrhyncha: Coccoidea) based on nuclear small-subunit ribosomal DNA. Mol. Phylogen. Evol. 25: 43-52.

DANZING E.M. 1997: Intraspecific variation of taxonomic characters. In Ben-Dov Y. \& Hodgson C.J. (eds): Soft Scale Insects: Their Biology, Natural Enemies and Control. Vol. 7A. Elsevier, Amsterdam, pp. 203-212.

Erlandson M., Braun L., Baldwin D., Soroka J., Ashfaq M. \& Hegedus D. 2003: Molecular markers for Peristenus spp. (Hymenoptera: Braconidae) parasitoids associated with Lygus spp. (Hemiptera: Miridae). Can. Entomol. 135: 71-83.

Gadagkar S.R., Rosenberg M.S. \& Kumar S. 2005: Inferring species phylogenies from multiple genes: concatenated sequence tree versus consensus gene tree. J. Exp. Zool. (B) 304: 64-74.

Gariepy T.D., Kuhlmann U., Gillott C. \& Erlandson M. 2007: Parasitoids, predators and PCR: the use of diagnostic molecular markers in biological control of arthropods. $J$. Appl. Entomol. 131: 225-240.

Gul H.G., BaJwa A. \& Panhwar G.N. 1997: Integrated control of mango mealybug Drosicha stebbingi Green (Hemiptera: Margarodidae) infesting forestry tree species at the Pakistan Forest Institute, Peshawar. Pakist. J. Forest. 47: 65-72.

Gullan P.J. \& CoOK L.G. 2007: Phylogeny and higher classification of the scale insects (Hemiptera: Sternorrhyncha: Coccoidea). Zootaxa 1668: 413-425.

Hardy N.B., Gullan P.J. \& Hodgson C.J. 2008: A subfamilylevel classification of mealybugs (Hemiptera: Pseudococcidae) based on integrated molecular and morphological data. Syst. Entomol. 33: 51-71.

Hebert P.D.N., Cywinska A., Ball S.L. \& de WaArd R. 2003: Biological identifications through DNA barcodes. Proc. $R$. Soc. Lond. (B) 270: 313-321.

LATIF A. 1949: The taxonomic status of Drosicha stebbingi (Green) and Drosicha mangiferae (Green) (Hem., Coccid.). Bull. Entomol. Res. 40: 351-354.
Latif A. 1961: Further Studies on Genera Drosicha, Drosichiella and Heterococcus of Family Coccidae: Homoptera. Ph.D. Thesis, University of the Punjab, Lahore.

Li H.-M., Deng R.-Q., Wang J.-W., Chen Z.-Y., Jia F.-L. \& WANG X.-Z. 2005: A preliminary phylogeny of the Pentatomomorpha (Hemiptera: Heteroptera) based on nuclear $18 \mathrm{~S}$ rDNA and mitochondrial DNA sequences. Mol. Phylogen. Evol. 37: 313-326.

Linares M.C., Soto-Calderon I.D., Lees D.C. \& Anthony N.M. 2009: High mitochondrial diversity in geographically widespread butterflies of Madagascar: a test of the DNA barcoding approach. Mol. Phylogen. Evol. 50: 485-495.

MilLER I.M. 2002: Mealybug genera (Hemiptera: Pseudococcidae) of South Africa: identification and review. Afr. Entomol. 10: $185-233$.

MiLLER S.E. 2007: DNA barcoding and the renaissance of taxonomy. Proc. Nat. Acad. Sci. USA 104: 4775-4776.

Moore D. 2004: Biological control of Rastrococcus invadens. Biocontr. News Inform. 25: 17N-27N.

Morse G.E. \& Normark B.B. 2006: A molecular phylogenetic study of armored scale insects (Hemiptera: Diaspididae). Syst. Entomol. 31: 338-349.

Mowry T.M. \& Barbour J.D. 2004: Distinguishing the parasitic wasp, Peristenus howardi, from some of its congeners using polymerase chain reaction and restriction endonuclease digestion. J. Insect Sci. 4: 25, available online: insectscience.org/ 4.25 .

Rung A., Scheffer S.J., Evans G. \& Miller D. 2008: Molecular identification of two closely related species of mealybugs of the genus Planococcus (Homoptera: Pseudococcidae). Ann. Entomol. Soc. Am. 101: 525-532.

Simon C., Frati F., Beckenbach A., Crespi B., Liu H. \& Flook P. 1994: Evolution, weighting, and phylogenetic utility of mitochondrial gene sequences and a compilation of conserved polymerase chain reaction primers. Ann. Entomol. Soc. Am. 87: 651-701.

Sundararaj R. \& Devaraj R. 2010: Record of mango mealybug, Rastrococcus iceryoides (Green) (Pseudococcidae: Hemiptera) on Pongamia pinnata (L.) Pierre in Karnataka. Indian Forest. 136: 269-270.

Tamura K., Dudley J., Nei M. \& Kumar S. 2007: MEGA4: molecular evolutionary genetics analysis (MEGA) software version 4.0. Mol. Biol. Evol. 10.1093/molbev/msm092.

TANDON P.L. \& LAL B. 1978: The mango coccid Rastrococcus iceryoides Green (Homoptera: Coccidae) and its natural enemies. Curr. Sci. 13: 46-48.

UnRUH C.M. \& GULLAN P.J. 2008: Molecular data reveal convergent reproductive strategies in iceryine scale insects (Hemiptera: Coccoidea: Monophlebidae), allowing the re-interpretation of morphology and a revised generic classification. Syst. Entomol. 33: 8-50.

Watson G.W. \& Kubiriba J. 2005: Identification of mealybugs (Hemiptera: Pseudococcidae) on banana and plantain in Africa. Afr. Entomol. 13: 35-47.

WiLliams D.J. 1986: Rastrococcus invadens sp. n. (Hemiptera: Pseudococcidae) introduced from the Oriental Region to West Africa and causing damage to mango, citrus and other trees. Bull. Entomol. Res. 76: 695-699.

Willink E. \& Moore D. 1988: Aspects of the biology of Rastrococcus invadens Williams (Hemiptera: Pseudococcidae) as pest of fruit crops in West Africa and one of its primary parasitoids Gyranusoidea tebygi Noyes (Hemiptera: Encyrtidae). Bull. Entomol. Res. 78: 709-715.

Received March 4, 2011; revised and accepted May 31, 2011 